\title{
Overview of the main powertrain architectures for hybrid and electric vehicles
}

\section{Visão geral sobre as principais arquiteturas do sistema propulsor para veículos híbridos e elétricos}

\author{
Rafael Garbelini Lorena ${ }^{1}$; Eduardo Kazumi Yamakawa ${ }^{2}$
}

\begin{abstract}
The research for alternative solutions to assist the propulsion, fuel converters and energy storage systems (ESS) in vehicular applications has become the focus of many institutions and mainly in the automotive industry, aiming to reduce the impacts caused by the emission of gases in the exhaust pipe and to improve energy efficiency in the worldwide vehicle fleet. Hybrid Electric Vehicles (HEV) and Electric Vehicles (EV) are currently a reality and meet this requirement to build a greener and less polluting society. In this context, this paper describes the operational characteristics of the different powertrain architectures employed in hybrid electric vehicles, including series, parallel and series-parallel topologies, as well as battery-powered and fuel cell electric vehicles. Finally, some of the elementary issues facing these advanced vehicular technologies, including the challenges for market penetration are highlighted.
\end{abstract}

Keywords: Hybrid electric vehicles. Electric vehicles. Electric powertrain.

\section{Resumo}

A pesquisa por soluções alternativas que auxiliem na propulsão, conversão e armazenamento de energia em aplicações veiculares, vem se tornando o foco da indústria automotiva na busca por reduzir os impactos causados pela emissão de gases na linha de escape e melhorar a eficiência energética veicular. Os veículos híbridos elétricos e elétricos, já são realidade nos dias atuais e vem ao encontro com a necessidade de construir uma sociedade menos poluente. Dentro deste contexto, este artigo descreve as características operacionais das diferentes arquiteturas do sistema propulsor empregadas nos veículos híbridos elétricos, incluindo as topologias em série, paralelo e série-paralelo, bem como dos veículos elétricos movidos a baterias e com sistema de células a combustível. Finalmente, algumas das principais questões fundamentais que atualmente enfrentam essas tecnologias veiculares avançadas, incluindo os desafios para a penetração no mercado, são destacadas.

Palavras-chave: Veículos híbridos elétricos. Veículos elétricos. Sistema propulsor elétrico.

\footnotetext{
${ }^{1}$ Master Program in Technology Development, LACTEC, Curitiba, Paraná, Brazil; E-mail: rafaelglorena@ hotmail.com

2 Prof. Dr., Power System R\&D, LACTEC, Curitiba, Paraná, Brazil; E-mail: eduardo@lactec.org.br
} 


\section{Introduction}

Powertrain is the system composed by a group of components from a motor vehicle, responsible to convert power into movement, providing driving force to the wheel and propel the vehicle. Different sorts of powertrain configurations can be reach in order to improve vehicle's performance and global energy efficiency (DAS; TAN; YATIM, 2017). Conventional systems are basically composed by internal combustion engine (ICE), gear box transmission and driveshafts (HEYWOOD, 2018).

In this work, powertrain system can be defined as of the energy source and the energy converter or power source (EHSANI, 2018). The inclusion of hybrid sources of power using electric machines came across with the necessity to reduce fuel consumption and the exhaust gas emissions. According to International Energy Agency Report (2015), around 30

In the last ten years, a technical and scientific effort has been made from different areas related to the development of alternative propulsion systems. In general, the common objective of the most recent publications is to explore the technical characteristics aiming to increase the energy efficiency of the powertrain system, contributing to the reduction of greenhouse gases emissions released to the environment by the automotive sector (SHUSHENG et al., 2020).

Total electric powertrain is the ultimate objective to reach in order to mitigate the usage of fossil fuels as energy source, however this transportation model struggles with some characteristic issues. The major concerns rely over the low battery density, which limit the vehicle's driving range (CANO et al., 2018). On the other hand, long charging times is required when compared to re-fuel the conventional vehicle with ICE. Moreover, the wide introduction of Electric Vehicles (EV) requires significant changes in the electric grid infrastructure with the aim of absorb an increased numbers of energy consumers at the same time (LANZAROTTO et al., 2018).

The hybridization of the conventional powertrain systems gives rise to the Hybrid Electric Vehicles (HEV) and have an important role as an intermediate transportation model before fully-electric powertrains. Combining the advantages of ICE vehicles and EV, HEV configuration can be classified depending on the hybridization factor which is the ratio of the electric motor power to the total power (WILBERFORCE et al., 2017), presented in the equation (1)

$$
H_{F}=\frac{P_{E M}}{P_{E M}+P_{I C E}},
$$

where $P_{E M}$ is the electric motor power and $P_{I C E}$ the internal combustion engine output power. In case of conventional vehicles powered by ICE, the hybridization factor is equal to zero, while a factor equals to one represents fully-electric vehicles. In between zero and one, many possible hybrid solutions can be obtained (SOMÀ, 2017).

In the automotive engineering field, hybridization factor has been exhaustively studied, considering its effects on vehicle performance, resulting in improvement on fuel economy (DAS; TAN; YATIM, 2017). Different powertrains architectures combinations and their specification are explored in this paper.

\section{Technical overview}

Vehicles can be classified according to the powertrain system configuration. An overview about the main architectures and topologies of hybrid and electric vehicles are presented in Figure 1.

Figure 1 - EV and HEV classification.

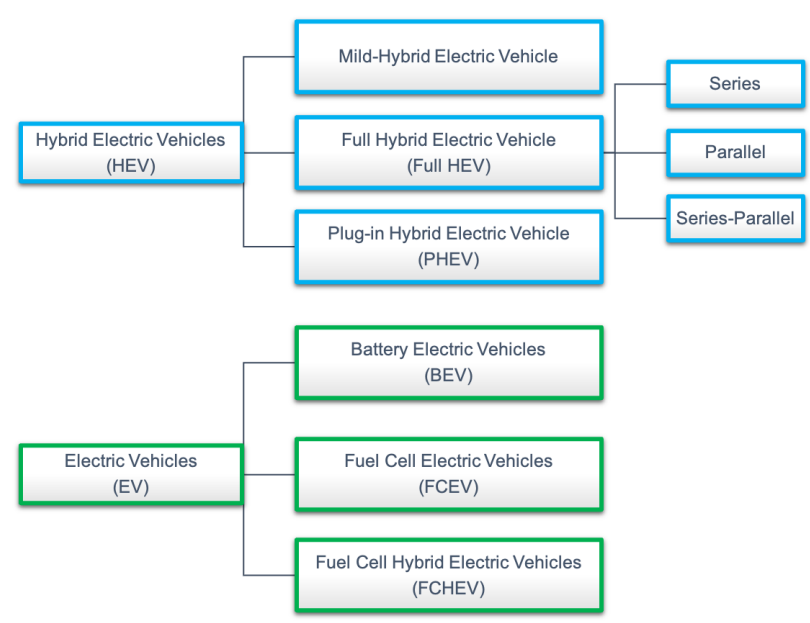

Source: Adapted from Wilberforce et al. (2017).

\section{Hybrid Electric Vehicles (HEV)}

At its most basic essence, powertrain is required to convert enough power to supply vehicle's performance demand, carry sufficient energy onboard to support the vehicle while driving, uphold high efficiency operation and emit low exhaust gas pollutants (EHSANI, 2018). 
In order to satisfy above conditions at outstanding and competitive performance level, the combination of two powertrain systems is mandatory.

Vehicles combining two or more powertrain systems can be classified as hybrid, Figure 2 shows the concept of hybrid powertrains and possible different power flow, depending on the application. Powertrain can supply its power to load through different power flows pattern, as described in Figure 2.

Figure 2 - Concept of hybrid powertrain.

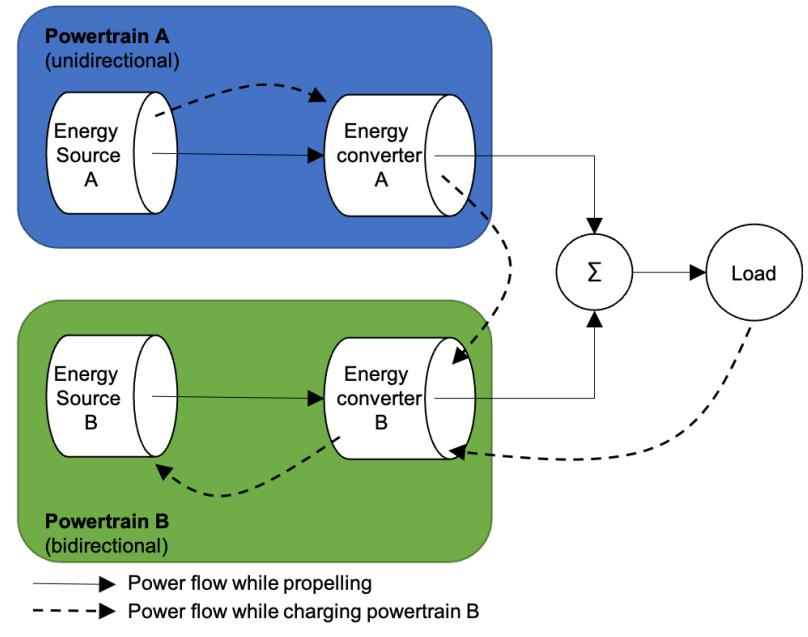

Source: Adapted from Ehsani et al. (2018).

Powertrain A is unidirectional and can be represented by the ICE with fuel tank as energy source, while powertrain B is bidirectional which can be illustrated by an electric motor with battery pack as energy source. According to Ehsani (2018), many operations patterns can be obtained to meet load requirements and are briefly describe:

P1. Powertrain B alone propel the vehicle.

P2. Powertrain A and B simultaneously propel the vehicle;

P3. Powertrain B receive energy from load (e.g., regenerative braking);

P4. Powertrain B receive power from powertrain A (e.g., to charge the battery pack);

P5. Powertrain B receive power from powertrain A and from the load simultaneously;

P6. Powertrain A delivers power to powertrain B and to the load at same time;

P7. Powertrain A delivers the power to powertrain B and powertrain B propel the vehicle;

P8. Powertrain A propel the vehicle and load delivers energy to powertrain $\mathrm{B}$.
In pattern $\mathrm{P} 1$ shown above, it is assumed that the propulsion is under the sole responsibility of the ICE; this situation can occur when the battery pack from powertrain B is empty and powertrain A does not have enough remaining energy to recharge the system B. P2 shows the situation where the propulsion is exclusively electric by the system $B$, this can happen in operating regions where the energy efficiency of the ICE is low (e.g., at low rotations in an urban cycle). P3 is the mode where both propulsion systems act simultaneously, which happens when there is a high demand for power, such as overtaking at the highway. $\mathrm{P} 4$ is related to the regenerative braking mode, where the vehicle's kinetic energy is recovered by the electric motor acting as a generator, and directing this recovered energy to the battery pack. In P5, it is the mode where the internal combustion engine recharges the batteries when the vehicle is stationary, or in situations where it does not demand power from the ICE, such as on lengthy descending slopes. P6 happens when the battery system is recharged by the ICE and the regenerative braking system at the same time P7 occurs when the ICE is responsible to propel de vehicle and recharge the battery system from powertrain B simultaneously. P8 is when the ICE recharges the battery pack from powertrain B and the electric motor drives the vehicle. The variety of operating modes that a hybrid powertrain can work creates greater flexibility when compared to a vehicle with single powertrain (EHSANI et al., 2018).

The architecture of hybrid electric vehicles can be defined based on the connection link between the components that define the power flow routes and control ports (EHSANI et al., 2018). Three of the most common architectures solutions found for HEV are presented in Figures 3,4 and 5 respectively.

In Figure 3 is possible to understand the series hybrid configuration. In this case, the electric motor is the only system mechanically connected to the transmission to drive the wheels, while the ICE is responsible to assist as power supply, converting mechanical energy from the combustion engine into electric energy directly to the power converter which has the function of electric coupling and control the power flows from the batteries and generator to the electric motor, or in the other way from electric motor to the battery pack. Fuel tank, ICE and generator consist of the primary energy source to recharge battery system or to deliver electric power directly to the traction motor (DAS; TAN; YATIM, 2017). All possible operating modes of $\mathrm{HEV}$ with series configuration have been described earlier as P2, P3, P4, P5, P6, P8 and P9. 
Being the ICE mechanically not coupled to the transmission system, it can be controlled to work in optimal torque and speed conditions.

Figure 3 - Series hybrid architecture.

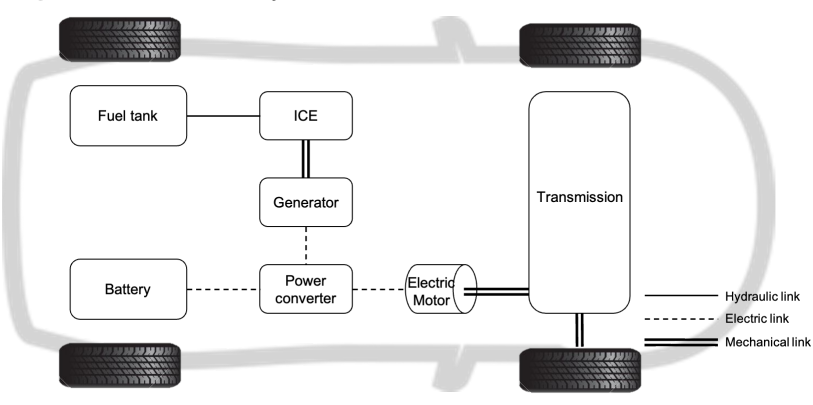

Source: Adapted from Ehsani et al. (2018).

Figure 4 - Parallel hybrid architecture.

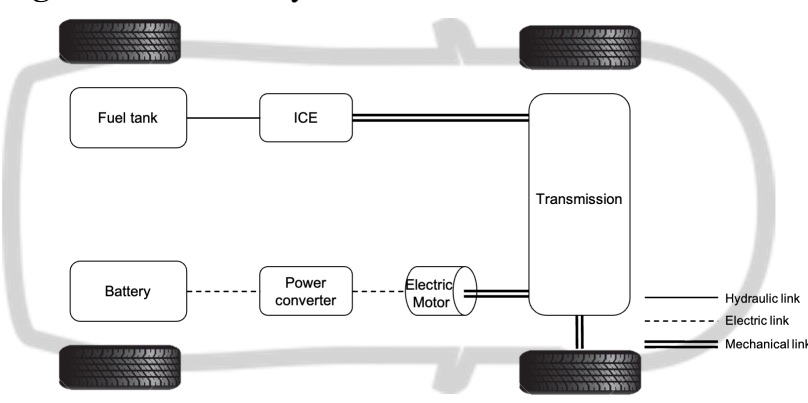

Source: Adapted from Ehsani et al. (2018).

Figure 5 - Series-parallel hybrid architecture.

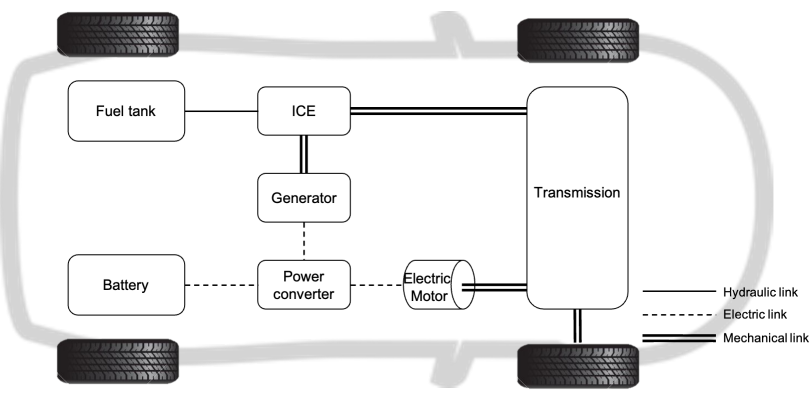

Source: Adapted from Ehsani et al. (2018).

However, being all the energy generated by ICE, converted into electrical power and then converted back into mechanical power, additional losses are introduced (LANZAROTTO et al., 2018).

Figure 4 shows the parallel hybrid configuration, where both electric motor and ICE systems can contribute independently or simultaneously to propel the vehicle through a mechanical coupling transmission system. Patterns P1, P2, P3, P4 and P9 can be achieved with this configuration since there is no link between ICE system and electric motor system. In the parallel hybrid powertrain, both engine and electric motor are connected to the transmission system delivering driving force to the wheels with no energy conversion occurs during the operation; consequently, the energy loss is diminished (EHSANI et al., 2018).

In case of the series-parallel architecture, Figure 5, it is a combination of both series and parallel configurations. Two power coupling are required for this application, one mechanical in the transmission system and one electrical by the power converter. The combination of the advantages from series and parallel architectures allows the seriesparallel hybrid powertrain to covers a wider range of the patterns described earlier, but also increase the complexity of the entire system (EHSANI et al., 2018).

The introduction of different hybrid technologies is already a reality in developed countries, and is gradually being adopted in emerging countries. Some market barriers are still imposed on these technologies, since the vehicle's sales price is a decisive factor at the time of purchase by consumers (QUEIROZ, 2006). Figure 6 presents some of the hybrid technologies based on their level of complexity and penetration forecast in the market over the time. Micro hybrid solutions - basically consisted of start-stop system - are the most usual as they have a reduced levels of complexity and implementation cost when compared to Mid- and Fully-Hybrid solutions.

Figure 6 - Hybridization level over time.

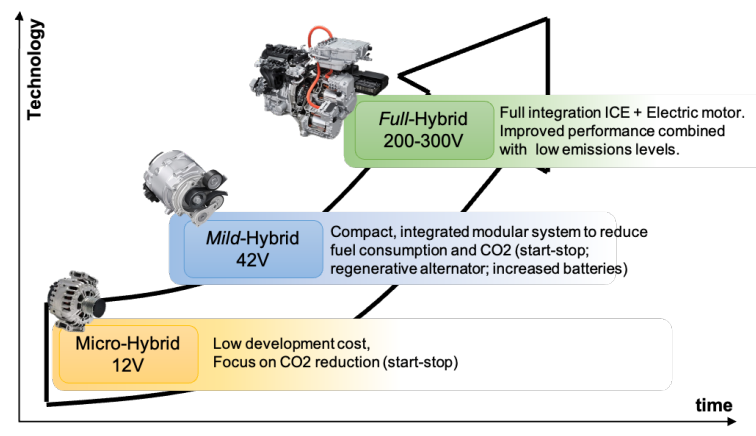

Source: Adapted from Queiroz (2006).

Hybrid electric vehicles and their different levels of hybridization play a fundamental role on improving the energy efficiency of the global fleet, and also serve as a bridge for the adoption of increasingly cleaner solutions, in terms of emissions and fuel consumption. It can be said that the hybrid propulsion system is an important transition phase for full electric vehicles, since a large part of the national infrastructure needs to be adequate to attend the needs of an increased electric vehicles fleet. 


\section{Electric Vehicles (EV)}

Electric vehicle applies one or more driving motors combined with electric machines to generate the traction force to the wheels and propel the vehicle. Its classification varies according to the energy source that feeds the electrical system, which can be through a set of batteries, fuel cells, ultra-capacitors, flywheels, or a sort of combination among them. The main advantages of an EV over a conventional vehicle with an internal combustion engine is the absence of exhaust gas emissions resulting from fuel combustion process, which leads to fuel independence from non-renewable sources, high energy efficiency, low operational noise, and others characteristics (EHSANI et al., 2018).

In general, an EV, Figure 7, can be divided into three main subsystems: Electric propulsion; Energy source and auxiliary subsystem. The electric propulsion subsystem, as the name implies, is responsible for vehicle propulsion and is composed of a vehicle controller, electric power converter, electric motor and transmission system. The energy source subsystem is responsible for storage and manages the power flow to the propulsion and auxiliary subsystem, which is composed by refueling unit, energy management unit and an energy source. Finally, the auxiliary subsystem is responsible for secondary systems (e.g., cabin climate control, lighting, panel, power steering wheel) and is composed by climate control unit, auxiliary power supply and power steering unit.

Figure 7 - Electric vehicle architecture.

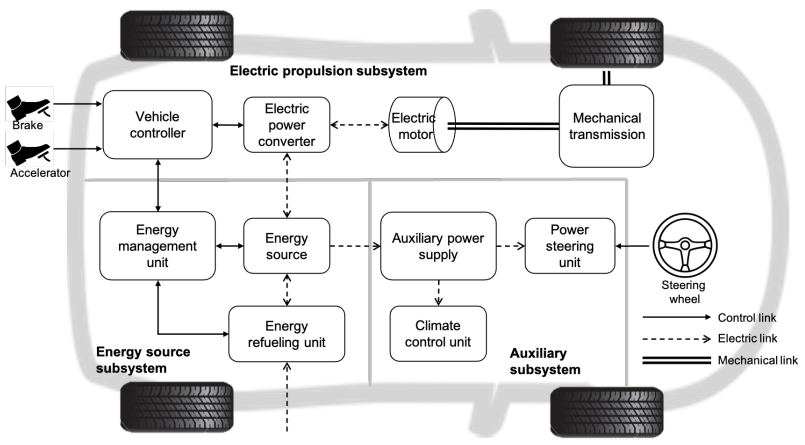

Source: Adapted from Ehsani et al. (2018)

Based on input signals from the brake and accelerator pedal, the vehicle controller sends signal to the power converter, which regulates the power flow between the propulsion subsystem and the energy source. The backwards power flow from wheels to the energy source is obtained with the regenerative braking system, and this power can be restored by the battery system and used to either supply energy to electric motor or to auxiliary subsystem (DAS; TAN; YATIM, 2017). The energy management unit works in conjunction with the vehicle control unit to manage the regenerative braking system, and also with the supply unit to control and monitor the energy level and usage mode of the energy source. The auxiliary power supply contributes to the necessary power at different voltage levels for all auxiliary systems, especially the climate control and power steering units (EHSANI et al., 2018).

In line to the schematics in Figure 1, EVs can be classified according to the primary energy source. Three main architectures are covered:

(i) Battery electric vehicles (BEV);

(ii) Fuel cell electric vehicles (FCEV);

(iii) Fuel cell hybrid electric vehicles (FCHEV).

The BEV model, shown in Figure 8, requires the battery pack as primary energy source, which is assembled in the vehicle and allows it to be recharged through the charging unit. Electric vehicles in general have higher flexibility when compared to traditional vehicles with ICE and, in some configurations, the electric motor is able to control speed and torque levels, replacing the transmission system. Consequently, fewer mechanical components contribute to reduction of frictional losses and rotational inertia of the system, resulting in increased efficiency of the powertrain during the conversion of electrical energy to mechanical energy (DAS; TAN; YATIM, 2017). In the application illustrated in Figure 8, the electric motor is powered by a DC source (battery set) which has an approximately constant terminal voltage. Thus, a power unit control - composed by a converter DC/DC and inverter - is required adjust the voltage and frequency to the DC electric motor.

Figure 8 - Battery electric vehicle architecture.

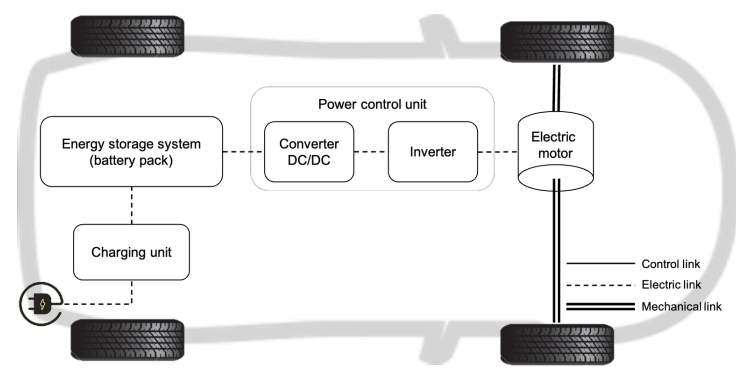

Source: Adapted from Das, Tan and Yatim (2017). 
Similar to the EV, the fuel cell electric vehicle is also propelled by an electric system, being required or not a mechanical transmission to transfer the torque and power to the wheels. As shown in Figure 9, the main difference is the primary source of energy, based on the fuel cell pack, also known as electrochemical cell, capable of converting potential energy from a fuel into electricity through an electrochemical reaction (WILBERFORCE et al., 2017). Hydrogen is the most common fuel used in fuel cells, but some cells technologies allow the usage of methanol, ethanol and others hydrocarbon fuels.

Figure 9 - Fuel cell electric vehicle architecture.

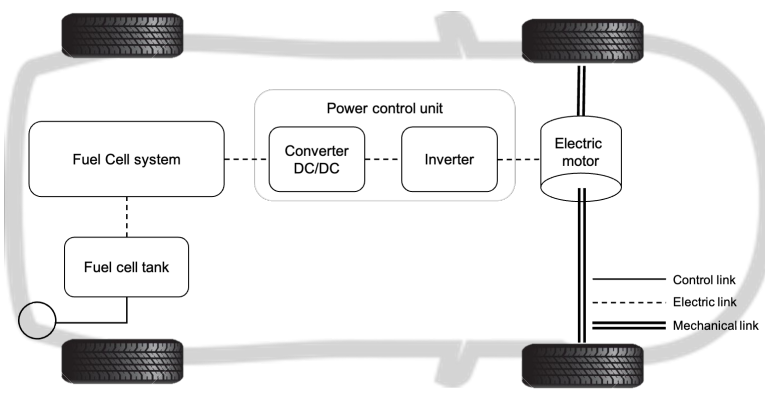

Source: Adapted from Das, Tan and Yatim (2017).

Compared to battery-powered electric vehicles, the fuel cell vehicle has the advantages of longer driving range without the necessity to recharge the vehicle, also the refiling time can be dramatically reduced (WILBERFORCE et al., 2017). When compared to conventional vehicles with internal combustion engines, it has the advantages of high energy efficiency and the reduced amount of exhaust gas emissions due to the direct conversion of free energy from the fuel into electrical energy, through the electrochemical reaction without the combustion process (EHSANI et al., 2018). One of the main characteristics of fuels cell is that the reactants are supplied directly from external sources (e.g., gaseous hydrogen) unlike batteries which the reactants are stored internally (WILBERFORCE et al., 2017).

The last architecture is the fuel cell hybrid electric vehicles, presented in Figure 10, which adopt auxiliary sources to storage energy in a hybrid way to the fuel cell system. Electrochemical batteries are used as an energy storage system, as they can be charged and discharged based upon the demand of the propulsion and auxiliary subsystems. In some specific applications, ultra-capacitors can be implemented to assist in energy storage and supply peak demand of electric power from the powertrain (DAS; TAN; YATIM, 2017).
Figure 10 - Fuel cell hybrid electric vehicle architecture.

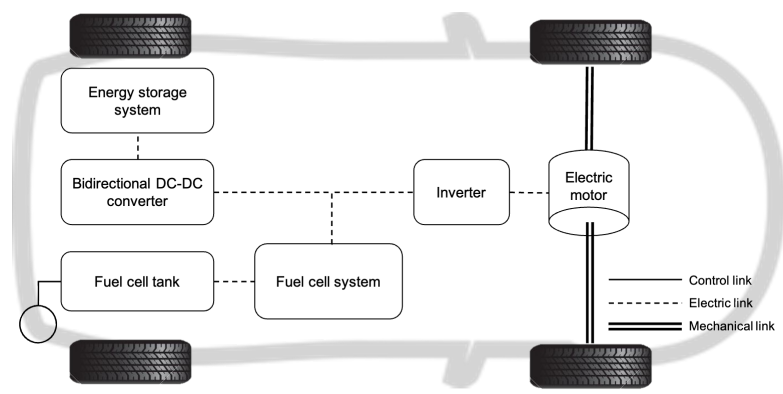

Source: Adapted from Das, Tan and Yatim (2017).

In this solution, the energy converted in the fuel cell system is stored in the energy storage system (ESS). The bidirectional converter is responsible to control the energy flow from fuel cell system during charging process and supplies the required energy by the propulsion subsystem during the discharging process.

The different powertrains technologies used for vehicle propulsion, as well as the main diversity of energy sources used as fuel over the time are shown in Figure 11.

Figure 11 - Propulsion strategy and energy diversity.

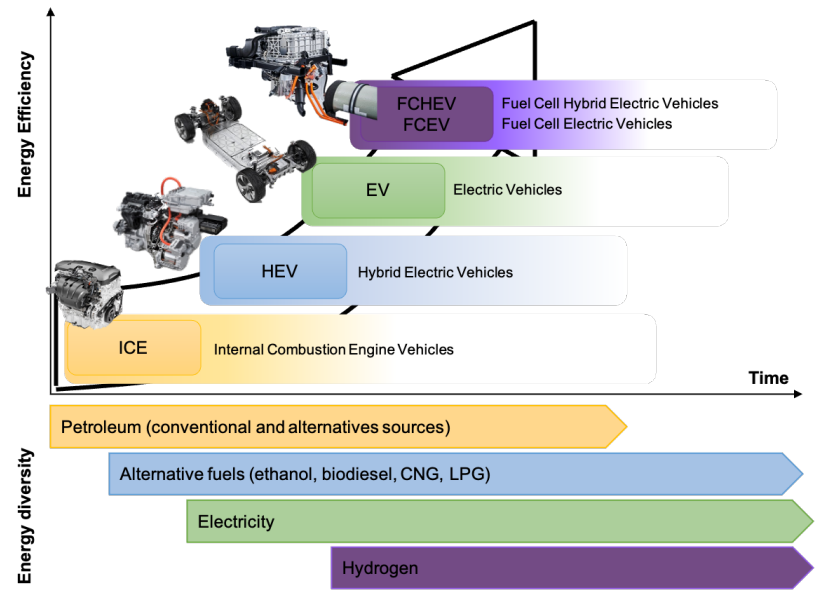

Source:Adapted from Wilberforce et al. (2017).

The electric vehicle comes as a key player to reduce the exhaust gas emission that are harmful to the environment, mitigating the effects of climate changes, reducing toxic pollutants and be in place to replace the reserves of fossil fuels (WILBERFORCE et al., 2017). Several technical challenges ahead need to be overcome, mainly related to the operational limitation of the current batteries available in the market as well as infrastructure challenges and difficulties for a capable charging station network to cover vast territories and the implications of overloading the current national electrical power grid. 
According to an electromobility study carried out by EPE, Empresa de Pesquisa Energética (EPE, 2018), the prospect of hybrid and electric vehicle technologies penetration in Brazil will have significant impacts on the national fleet in the coming years, presenting from the most optimistic perspective, the complete replacement of vehicles with internal combustion engines by hybrids and electric vehicles until 2045, Figure 12.

Figure 12 - Penetration curve of hybrid and electric vehicles in the national fleet.

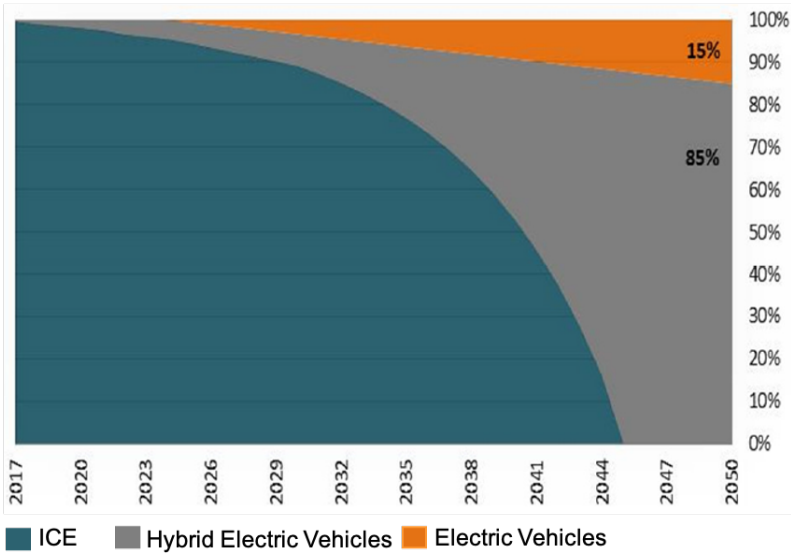

Source: EPE (2018).

\section{Conclusion}

The electric vehicle is already a reality in the more developed countries, but still have some barriers imposed in developing markets with diminished infrastructures (e.g., lack of charging stations) and high purchase prices. The hybrid propulsion system came as an alternative proposal to improve the energy efficiency and decrease the dependency of conventional fossil fuels as well as reduce the exhaust gas emissions levels release by the automotive industry to the environment. In a short-term scenario, hybrid architectures are seeing to be the most suitable intermediate solution which precedes the large-scale adherence of full electric vehicles worldwide. With the increase of oil price, the demand for hybrid powertrains configurations is likely to growth. The competition among the automakers is heating up to see who will get the major EV and HEV market share.

Series-parallel hybrid architecture is recognized to be the most popular for all HEV applications. In this configuration, the system is able to operate in a wide range of set up modes, including all-electric operation. In case of EV topologies, BEV is the most suitable application as of today, since fuel cell technology still has a number of problems related to hydrogen storage system and also its high development cost, but have shown as a potential candidate solution for EV's primary source of energy in the future.

\section{Acknowledgments}

The authors wish to thank professional master's program in technology development, offered by Lactec in partnership with the Paraná Institute of Engineering.

\section{References}

CANO, Z. P.; BANHAM, D.; YE, S.; HINTENNACH, A.; LU, J.; FOWLER, M.; CHEN, A. Batteries and fuel cells for emerging electric vehicle markets. Nature Energy, London, v. 3, n. 4, p. 279-289, 2018. DOI: 10.1038/s41560018-0108-1.

DAS, H. S.; TAN, C. W.; YATIM, A. H. M. Fuel cell hybrid electric vehicles: A review on power conditioning units and topologies. Renewable and Sustainable Energy Reviews, Amsterdam, v. 76, p. 268-291, 2017. DOI: https://doi.org/10.1016/j.rser.2017.03.056.

EHSANI, Mehrdad et al. Modern electric, hybrid electric, and fuel cell vehicles. Florida: CRC press, 2018.

EPE - EMPRESA DE PESQUISA ENERGÉTICA. Plano Nacional de Energía - 2050. Rio de Janeiro: EPE; Brasília: Ministério de Minas e Energia, 2018.

HEYWOOD, J. B. Internal combustion engine fundamentals. New York, McGraw-Hill Education, 2018.

KÖRNER, Alexander et al. Technology roadmaphydrogen and fuel cells. Paris: International Energy Agency, 2015.

LANZAROTTO, D. et al. Overview of different hybrid vehicle architectures. IFACPapersOnLine, [s. l.], v. 51, n. 9, p. 218-222, 2018. DOI: https://doi.org/10.1016/j.ifacol.2018.07.036.

QUEIROZ, J. F. Introdução do veículo hibrído no Brasil: evolução tecnológica alianda à qualidade de vida. 2006. Dissertação (Mestrado) - Universidade de São Paulo, São Paulo, 2006.

SHUSHENG, X. et al. Research and development of on-board hydrogen-producing fuel cell vehicles. International Journal of Hydrogen Energy, Oxford, v. 45, n. 35, p. 17844-17857, 2020. DOI: 10.1016/j.ijhydene.2020.04.236. 
SOMÀ, A. Trends and hybridization factor for heavy-duty working vehicles. In: DONATEO, T. (ed.). Hybrid Electric Vehicles. Londres: IntechOpen Limited, 2017. p. 11-12. DOI: 10.5772/intechopen.68296.
WILBERFORCE, T. et al. Developments of electric cars and fuel cell hydrogen electric cars. International Journal of Hydrogen Energy, Oxford, v. 42, n. 40, p. 25695-25734, 2017. DOI: https://doi.org/10.1016/j.ijhydene.2017.07.054. 